\title{
The Importance of Engaging Local People in Landscape Management - Experiences from an EU-Project
}

\author{
Kaisa J. Raatikainen \\ University of Jyvaskyla, Department of Biological and Environmental Science, P.O. Box 35; Fl-40014 University of Jyvaskyla, \\ Finland
}

\begin{abstract}
"Bull by the Horns" -project initiated landscape management and promoted biodiversity associated with diminishing High Nature Value farmland habitats in Finland. A specific focus was on grazed semi-natural grasslands and wood-pastures which are collectively referred to as traditional rural biotopes (TRBs). Collaboration among project workers, non-farming landowners, and cattle owners reintroduced grazing to abandoned pastures, and management was financed through agri-environmental payments. Using adaptive co-management principles, the project enabled collective definition of integrated site-specific management objectives. A better understanding of contemporary challenges and opportunities to advance TRB management cumulated through incorporation of local actors into collaborative management planning. Authority-driven measures failed to engage locals, but supporting existing networks among landowners and cattle farmers was successful. The project gave insight into good practices on collaborative landscape management, and it proved to be efficient in directing management actions to biologically valuable sites. Due to a short operative period and lack of follow-up procedures, the actual environmental outcomes of established management could not be verified. Concernedly, environmental administration is becoming heavily reliant on projects, which creates further risks because of their short time frames and narrow focus. Functional governance practices that are tested in projects should be consolidated through more permanent resources.
\end{abstract}

\section{Keywords:}

Adaptive co-management, Adaptive governance, Agri-environment scheme, Collaborative planning, High Nature Value farmland, Landscape management, Projectification

Submitted: 17 June 2016 / Accepted in revised form: 07 March 2018 / Published: 23 March 2018

\footnotetext{
*Corresponding author. Email: kaisa.raatikainen@jyu.fi

(C) The Authors. 2018. Landscape Online. This is an Open Access article distributed under the terms of the Creative Commons Attribution License (http://creativecommons.org/licenses/by/4.0), which permits unrestricted use, distribution, and reproduction in any medium, provided the original work is properly cited.
} 


\section{Highlights}

- "Bull by the Horns" -project introduced adaptive governance practices, collaborative planning techniques, and cooperative stakeholder networking in rural landscape management.

- Collaboration between local actors and planners working at regional level was found to be important in defining integrated management goals for traditional rural biotopes.

- Scale-related challenges emerged in conservation of traditional rural biotopes.

- Adaptive governance approaches such as adaptive co-management are needed to facilitate sustainable biodiversity conservation within rural landscapes.

\section{Introduction}

\subsection{Motivation}

Agricultural land-use intensification and land abandonment alike impact rural landscapes, communities, biodiversity, and ecosystem services (Beilin et al. 2014; Allan et al. 2015). In Europe, traditional land-use systems have historically been significant biodiversity drivers and their large-scale collapse has resulted in severe biodiversity loss (Plieninger et al. 2006). Certain agricultural practices, especially low-intensity grazing and mowing, are currently supported through agri-environmental incentives in order to conserve biodiversity and maintain traditional rural landscapes (Beaufoy \& Cooper 2013; Linnell et al. 2015). These High Nature Value (HNV) farming practices support or are associated with either a high species and habitat diversity or the presence of species of conservation concern, or both (Andersen et al. 2004; Beaufoy \& Cooper, 2013). They also maintain ecosystem services, such as food provision, but also many recreational, aesthetic, and spiritual benefits are tied to cultural landscapes with HNV farmland (Arico et al. 2005).
Many HNV farmlands have vanished because of agricultural intensification (Plieninger \& Bieling 2013). This has created conflicts between biodiversity conservation and agriculture throughout Europe (Henle et al. 2008; McGinlay et al. 2017). These conflicts are difficult to solve as the linkages between people and nature are complex in landscape management, which in essence is management of social-ecological systems (according to Folke 2006; Berkes et al. 2003). The problematic nature of conservation management in rural landscapes is illustrated with the case of traditional rural biotopes (TRBs) in Finland. TRBs are one type of HNV farmland habitats characterized by a high level of structural heterogeneity and species richness, and they host a variety of cultural values related to land-use history (Fig. 1). The term "traditional rural biotope" is used in Finland as referring to a range of habitats maintained through active management, including semi-natural grasslands, wood-pastures, and heaths (Schulman et al. 2008; Birge \& Herzon 2014). TRBs are classified as the most threatened of all Finnish ecosystems (Raunio et al. 2008), and they are an important habitat for 1,807 nationally red-listed species, many of which are insects living on dry meadows (Rassi et al. 2010).

In Finland, the only current nationwide means to encourage TRB management is via voluntary management contracts in the national agrienvironment scheme (AES) (Raatikainen et al. 2017). In these fixed-term AES payment contracts a farmer agrees to undertake certain management actions in order to provide supposed environmental benefits, and gets an annual fee in return (Armsworth et al. 2012). Typically, these incentives are focused on actions which otherwise would be unlikely to be undertaken (Primdahl et al. 2013). Unfortunately, the Finnish TRB management payments have often been allocated for sites that are not under any field survey that would have shown their biological value in terms of species richness or habitat quality (Kemppainen \& Lehtomaa 2009; Arponen et al. 2013; Raatikainen et al. 2017). Therefore efficient policies to promote TRB management are yet to be developed.

Because of the negative effects of agricultural modernization on biodiversity and cultural heritage, 


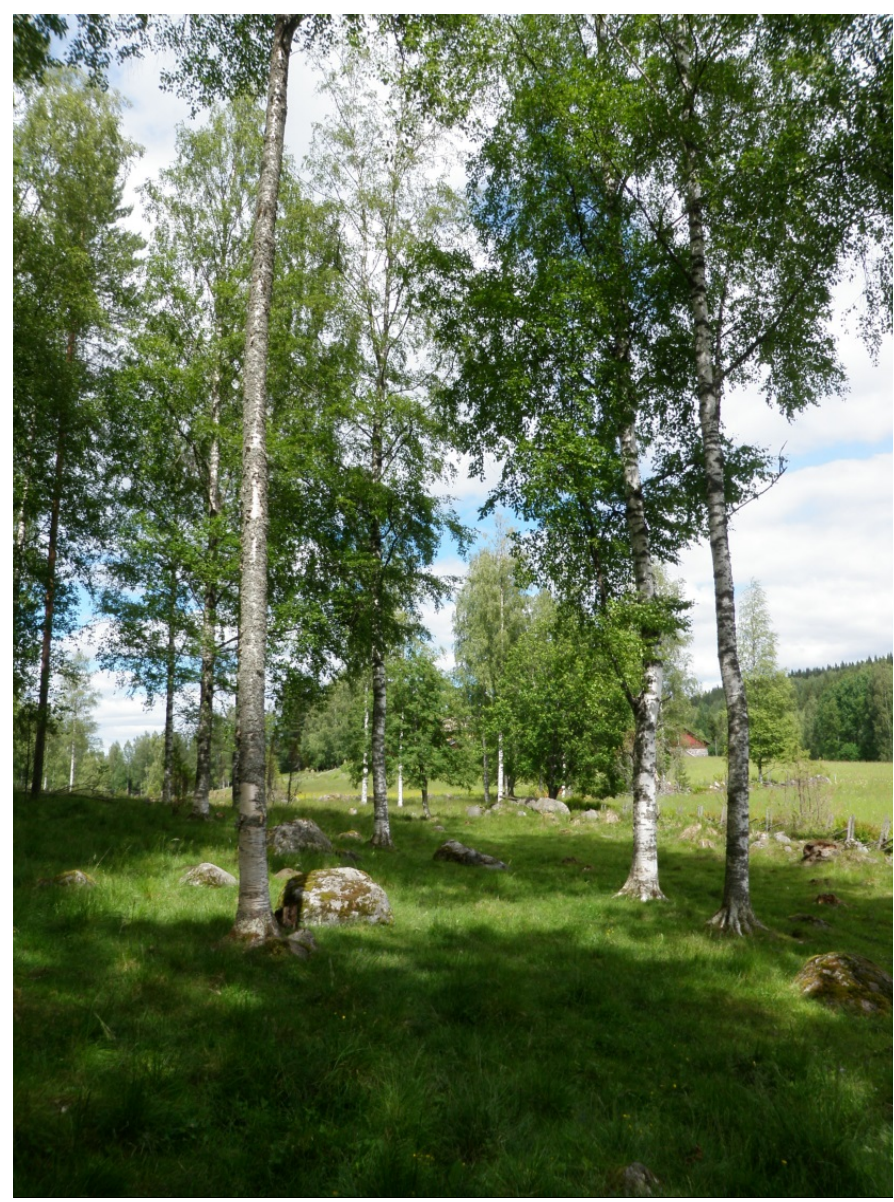

Figure 1: A sparsely wooded pasture is a typical traditional rural biotope type in Finland. Features that promote biodiversity include disturbances by grazing, heterogeneous tree structure, dead wood, rocks, animal dung, and small open meadow patches. On this particular site, historical land-use is reflected in visible remnants of slash-and-burn agriculture from early 20th century. These include a layer of coal within top soil, piles of stones that are removed from the cultivated area, and distinctive tree structure (birch regenerates spontaneously on burned ground; also, the oldest trees are of same age which indicates that the first tree generation established on open ground). Photo: Kaisa J. Raatikainen.

land-use priorities on TRBs have shifted from agricultural to conservational goals (Birge \& Fred 2011; Raatikainen \& Barron 2017). This contrasts the fact that TRB management is mainly conducted and funded as part of agriculture, being dependent on contemporary market-oriented agricultural production. The conflicts between Finnish conservation and agricultural policies are reflected in the lack of efficient governmental collaboration (Raatikainen et al. 2017). Instead, TRB-related issues have dissolved into isolated monosectoral strategies such as the Rural Development Programme (Ministry of Forestry and Agriculture, 2013) and Finland's national biodiversity strategy (Heikkinen 2007). This further complicates guiding TRBs towards a more sustainable conservation status. Similar situations are common in HNV farmland also elsewhere in Europe (Plieninger \& Bieling 2013). For example, effective agricultural and conservation policies concerning wood-pastures are currently lacking because institutional structures are traditionally organized within mono-functional sectors (Plieninger et al. 2015). Thus, the challenge in policy development is that wood-pastures, as other HNV farmland habitats, cross existing institutional boundaries by being simultaneously used for many purposes (such as agriculture, forestry, and recreation).

Improving TRB management is highly dependent on collaboration between farmers, officials, conservation researchers, and policy makers (Birge \& Fred 2011). Discussion and cooperation between different stakeholders and authorities is imperative in order to advance TRB management policies (Kaljonen 2008; McGinlay et al. 2017). The documentation of the collaborative process itself is important, because it explains how management targets can be achieved. The way in which this new knowledge feeds into decision-making should be analyzed in order to explore how policies are implemented and justified (Primmer et al. 2015). Yet, the effectiveness of biodiversity conservation policies has usually been evaluated through quantifiable outcomes and impacts, and the ways in which governance turns the policies into effective practices have received little attention (Primmer et al. 2015).

The critical state of TRBs calls for adopting new perspectives on their conservation and governance (Raatikainen et al. 2017; Raatikainen \& Barron 2017). These may be found within the broader frameworks of management of landscapes and social-ecological systems. With the acknowledgement of landscapes as the perceived dynamic outcomes of the action and interaction of natural and/or human factors (Council of Europe 2009), participatory interventions are becoming more and more common in guiding landscape management towards sustainability (Folke et al. 2005; Plieninger et al. 2006; Stenseke 2009; Primdahl et al. 2013). New adaptive governance policies are needed to navigate 
dynamic social-ecological systems, such as TRBs, through socio-economic change (Berkes et al. 2003; Folke 2006; Olsson et al. 2004; Folke et al. 2005). Collaborative governance promotes participation by bringing public agencies and non-state stakeholders together to collectively engage in consensusoriented decision-making (Ansell \& Gash 2007). By paying attention to the importance of knowledge accumulation, collective learning, and sensitivity to changes, these approaches emphasize sustainable governance outcomes (Primmer et al. 2015).

Adaptive co-management is one of the participatory frameworks that may offer tools for sustainable landscape management. Adaptive co-management is an interdisciplinary and collaborative approach to ecosystem governance, in which institutional arrangements and ecological knowledge are tested and revised in a dynamic, ongoing, self-organized process of learning by doing (Folke et al. 2002; Armitage et al. 2007; Armitage et al. 2009; Allen \& Garmestani 2015). Adaptive co-management creates arenas for different groups to involve in knowledge sharing and social learning (Olsson et al. 2004). These management stakeholders can operate at different levels and across scales, forming social, institutional, and ecological connections among individuals and organizations (Olsson et al. 2004; Folke et al. 2005; Berkes 2007; Armitage et al. 2009). Adaptive co-management aims to address case- and scale-specific social and ecological complexity and uncertainty in resource management flexibly by building resilience (Folke et al. 2002; Olsson et al. 2004; Folke et al. 2005; Armitage et al. 2009; Allen \& Garmestani 2015).

Parallel to collaborative and resilience-oriented approaches, there is an increased reliance on projects in implementing agri-environmental policies both in Europe and North America (Munck af Rosenschöld \& Wolf 2017). Conceptually, projects are action-oriented temporary organizational settings that aim to conduct certain well-defined tasks in order to achieve desired transitional changes in a limited time frame through team work (Lundin \& Söderholm 1995). In practice, projects can be used as means to develop and introduce new, innovative adaptive governance practices and policies, such as adaptive co-management (for examples, see Olsson et al. 2004). Action-oriented, fixed-term agri-environment schemes have become widespread in Europe. This development exemplifies projectification; i.e. expanded reliance on temporally bounded organizations (Munck af Rosenschöld \& Wolf 2017). Yet the success of action-oriented agrienvironmental schemes in producing beneficial outcomes for biodiversity has been variable (Kleijn \& Sutherland 2003; Uthes \& Matzdorf 2013; Batáry et al. 2015). More successful experiences have been gained through results-based agri-environment schemes, in which payments are directly linked to the desired environmental goals rather than to compensation of management costs (Matzdorf \& Lorenz 2010). Also results-based agri-environmental measures can be paralleled to projects. They, too, have specific objectives and limited time frames; between the beginning and the end of the payment contract the farmer conducts specified actions in order to achieve planned goals.

On broader level, projects can be used to initiate cross-sectoral practices that benefit HNV farmland conservation. During last ten years, several Finnish EU-projects have aimed to combine management of TRBs and cultural landscapes with modern cattle husbandry (Fig. 2). This paper will outline one of the projects, present its strengths and weaknesses, and discuss lessons learnt from it. "Bull by the Horns" is considered to be an illustrative example, since it was evaluated as demonstrating effective and exemplary landscape management and planning policies by Finnish environmental and agricultural administration, and as a result, it was presented as the Finnish candidate for European Landscape Award 2015 (Council of Europe 2009; 2015). The project's operating principles and measures provide insight into collaborative process and adaptive governance in landscape management.

\subsection{Goals of the study}

In this case study, "Bull by the Horns" -project's landscape management planning practices were explored within the adaptive co-management framework. In particular, following questions were addressed: (1) Did administrative representatives and project participants alike perceive the project as successful? and (2) To what extent project's 
operations fit into adaptive co-management framework? On broader level, this work discusses whether projectified landscape management can translate into adaptive governance targeted to meet conservation challenges within the context of contemporary agriculture.

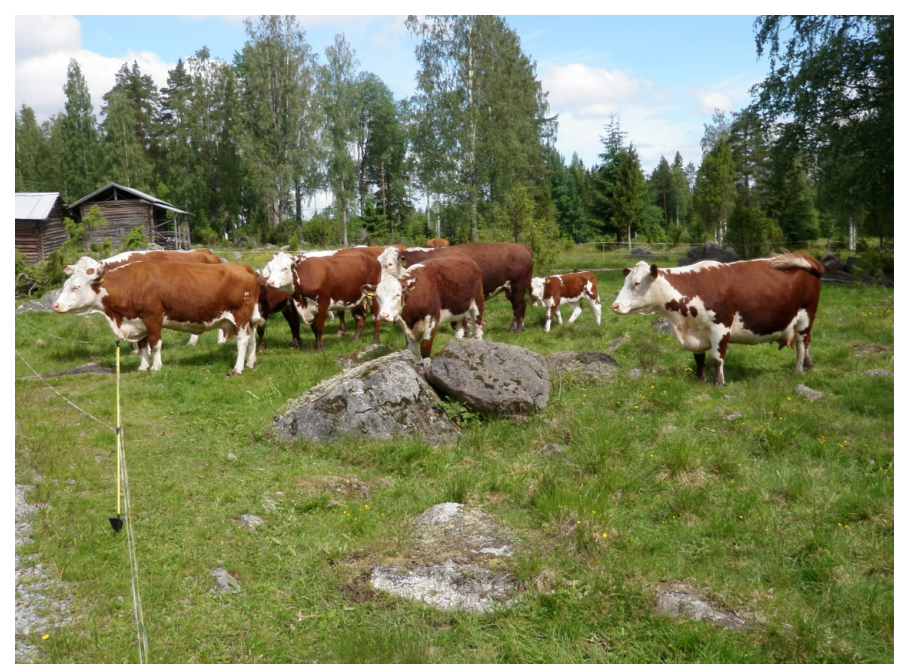

Figure 2: Pasturing modern cattle breeds on traditional rural biotopes has enabled the continuation of management. Especially farms with calver production have been interested in biodiversity and landscape management. Photo: Kaisa J. Raatikainen.

\section{Methods}

\subsection{Description of the project}

\subsubsection{General outline}

"Bull by the Horns" aimed to hinder biodiversity loss caused by agricultural intensification and promote multiple values within rural cultural landscapes by enhancing the use of grazing animals in landscape and TRB management. The project had following essential goals:

(1) Advance active management within rural landscapes in order to maintain HNV farmland.

(2) Plan and organize grazing for particular sites valuable in terms of biodiversity and cultural heritage.

(3) Increase the use of agri-environmental payments for landscape and TRB management.
(4) Diversify the economy of participating farms through incorporation of landscape management activities into farms' production basis, thereby improving their operational capabilities in the face of agricultural change.

(5) Engage local communities in efforts to promote biodiversity and manage local landscapes, and give advice to farmers and civic associations with regard to landscape management.

(6) Create functional cooperation networks that enable continued TRB and landscape management after the project has ended.

The project covered five administrative provinces; it comprised nearly $20 \%$ of the total area of Finland (Fig. 3). Within this region, management was planned for TRB sites, specified valuable landscapes, conservation areas, and Natura 2000 sites that benefited from low-intensity grazing. Management actions emphasized cattle, sheep, or horse grazing, but also mowing and removal of woody vegetation were utilized. A central idea was to bring together grazers in need of pastures and abandoned sites suitable for grazing. The project focused on arranging restoration and continuous management for sites challenging in terms of planning (i.e. large areas with several landowners, conserved areas, or areas hosting red-listed species), and on organizing (but not providing) the required funding to cover the costs of management actions.

The project organization included four regional authorities responsible for environmental protection and channeling of AES payments (Centres for Economic Development, Transport and the Environment, or "ELY Centres", for Central Finland, Pirkanmaa, South Savo, and South Ostrobothnia) and three non-governmental organizations providing advisory services for farming, including counseling on TRB and landscape management (Rural Women's Advisory Organisation of ProAgria Pirkanmaa, Rural Women's Advisory Organisation of ProAgria South Savo, and ProAgria Österbottens Svenska Lantbrukssällskap). During the operative period (1.6.2009-30.9.2012) the total budget of the project 


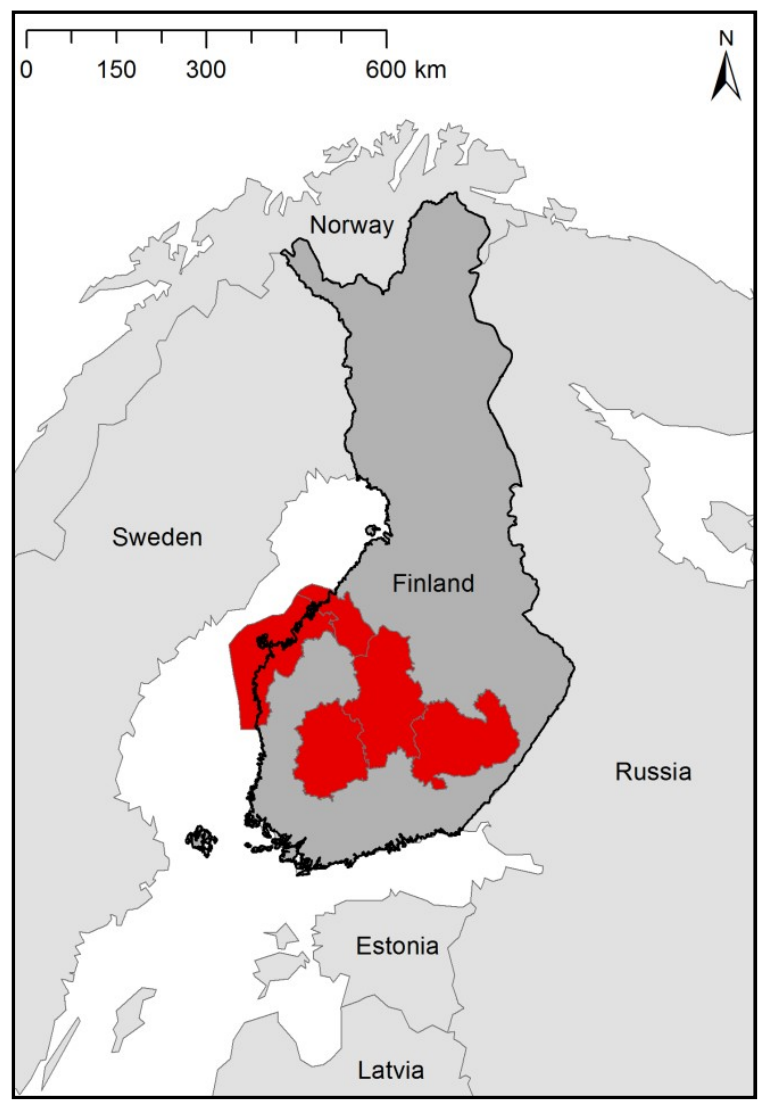

Figure 3: "Bull by the Horns" project region covered five provinces in Finland (colored in red). Administrative boundaries

by EuroGeographics and National Land Survey of Finland.

was $666900 €$. The funding came partially from the Finnish state and the European Agricultural Fund for Rural Development.

The project gathered knowledge on the functionality of TRB management measures in Finnish AES during period 2007-2014. Before that, TRB management was mainly supported through five-year AES contracts that provided payments for farmers who managed TRBs. These TRB management payments are considered the single most effective AES measure in terms of biodiversity conservation on agricultural land (Kuussaari et al. 2004). However, their total coverage has not reached the target level (Aakkula \& Leppänen 2014). In order to increase the coverage of managed TRBs, two new measures were taken into practice during the 2007-2014 period: TRB management payments were opened for civic associations (in addition to farmers, who have been able to apply the payments since 1995), and a two- year TRB restoration contract was introduced. Project workers specifically encouraged the usage of these new measures, in addition to promoting the earlier payment types that were already more familiar to the applicants. As the project's end coincided with the planning of the next AES period, the project manager participated in the working group for the preparation of AES 2014-2020. In this way, the feedback and experiences gained from the project were passed on to the national policy-making arena.

\subsubsection{Counseling on landscape and TRB management}

"Bull by the Horns" -project was based on voluntary participation of local actors, i.e. landowners, cattle farmers, and civic associations. For those interested in landscape management, counseling was provided by experts working in environmental administration and advisory organizations. These project workers gave case-specific advice on following issues: contacts among landowners of potential pastures and owners of grazing animals; suitable sitespecific management practices; and applying for AES payments for TRB management. Considering the latter, three particular action-oriented payment types were mentioned. These were payment for management of traditional rural biotopes, payment for enhancing of biological and landscape diversity, and non-productive investment payment for initial clearing and enclosing of valuable traditional rural biotopes ("TRB restoration payment" hereafter) (for the description of the whole AES, see Ministry of Agriculture and Forestry 2013). A total of 489 persons participated in the project by receiving advice in issues related to TRB or landscape management. In most cases, this included field visits and management counseling on the spot.

In addition, the project further developed an existing internet-based service for connecting cattle owners and landowners with each other. The website "Pasture Bank" (Pasture Bank 2017) is an online market place for people interested in renting either pastures or grazing animals. It also works as a channel for collecting and spreading information on landscape management. 


\subsubsection{Site-specific collaborative management planning}

Project participants eligible for receiving TRB and landscape management payments were offered an opportunity to enter a site-specific management planning process (Fig. 4). Project workers evaluated the suggested sites based on background information and field visits. A typical site was abandoned and owned by a person or several persons who did not keep grazing animals. In this case, a cattle owner willing to take the site into grazing was sought for. The landowner was interviewed in order to gain information on the land-use history of the site; this local knowledge was combined with the knowledge on practices of livestock grazing on TRBs upheld by the cattle owner. A biologist from ELY Centre provided knowledge on TRB ecology and biodiversity to the planning and a ProAgria advisor incorporated an entrepreneurial offset to the plan by tailoring the management actions and budget according to the managers' economic interests.

Ideally, the objectives of and the responsibilities on the management actions were cooperatively crafted within the planning process. This was pursued in order to ensure that all stakeholders were engaged in the planning process, and desirable biodiversity- and

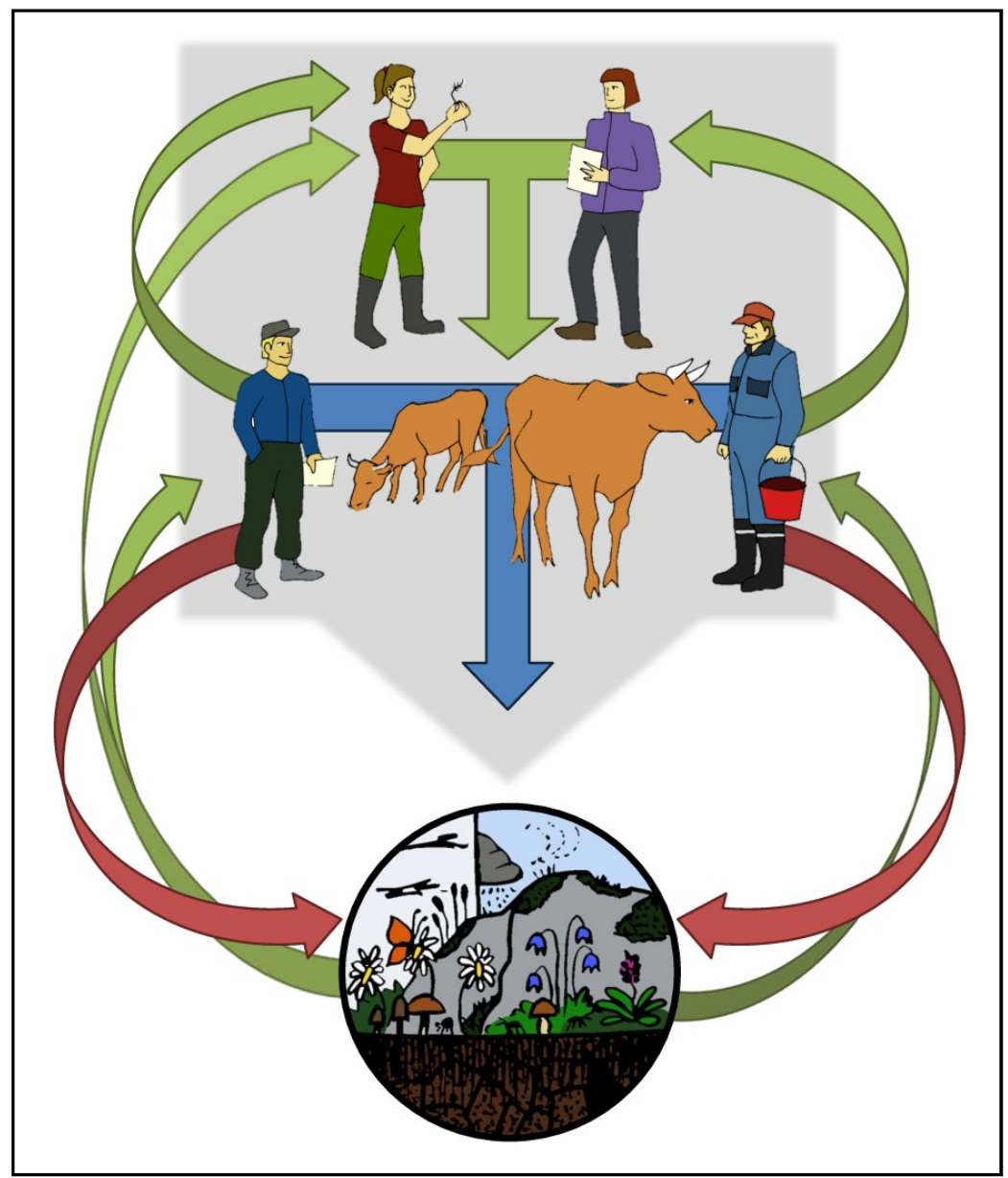

Figure 4:Site-specific collaborative management planning brought together biologists of regional authorities and non-governmental management advisors (project workers; top row) with landowners and cattle owners (local actors; middle row). The general aim of the management plan was to enhance the biodiversity, landscape value, and provision of ecosystem services related to the site (bottom circle) by introducing grazing. Green arrows represent the flows of information during the planning process. Knowledge was gathered on current biophysical attributes and land-use history of the site. These were coupled with the scientific knowledge of the project's workers and fitted to the economic framework of the manager's business (a cattle farmer or a civic association). In order to organize management and apply for funding, further cooperation between the landowner(s) and the manager was encouraged (networking; blue arrow). The viewpoints and interests of local actors (red arrows) were explored and integrated within the management plan. 
landscape-related aims were explained, reasoned, and coupled with suggested management practices. Most often the cattle owner took the responsibility on site management and rented the site from the landowner in order to apply for the management payment. Practical advice was given on both finding a suitable form of payment and the actual application process, but the manager carried the responsibility to apply for the payment him- or herself.

Detailed management plans were written for sites to facilitate the management activities and funding applications. Specific conservational objectives, e.g. safeguarding populations of red-listed species, were included when needed. Separate stage-wise plans for restoration and continuous management were prepared in order to restore management on abandoned sites. Project workers ensured that the content of the plans followed the necessary legislation and regulations of the AES.

\subsubsection{Large-scale landscape management planning}

Nine large-scale management plans were prepared for valuable cultural landscapes. This landscape level approach followed the principles of formerly established regional biodiversity management planning (Kaljonen 2008). Widening the scale of planning aimed at taking TRB connectivity and provision of certain cultural ecosystem services, such as aesthetic sceneries, better into account. Large-scale management plans suggested actions to promote heterogeneity of agricultural habitats and prevent overgrowth of landscapes within the planning region. Plans included general guidelines for landscape management and introduced the biological and cultural background of the region in question. Also different funding sources for management actions were listed. The maps and site descriptions in the plans pointed out locations that could be cleared, grazed, or mowed, and locations where special natural, cultural, historical, and aesthetic values existed.

\subsection{Data acquisition and analysis}

In order to detect participatory practices in the project, documents that described the project's operations were reviewed. Here information was collected on how administrative officials perceived the project and why they considered it to hold exemplary value for policy implementation. Next, experiences of local project participants were surveyed. In November 2016, a postal questionnaire was sent for 329 persons who had been involved in the project (see Supplementary material 1). The sample consisted of cattle farmers, landowners, and representatives of project's stakeholders. Their names and addresses were provided by the ELY Centre for Central Finland, the organization which led the project. The questionnaire form was accompanied with a cover letter and a selfaddressed prepaid envelope for returning the form. The questionnaire was filled anonymously, and it was established also on the internet (using Webropol 3.0). Further information on the opportunity to respond to the feedback questionnaire was spread through a network consisting of former project workers. Also social media was utilized to spread the questionnaire to potential respondents (blogging, Facebook, and Twitter).

The questionnaire consisted of two parts: the project's operation and the respondent's background information. The questions in the first part concerned those aspects of participation that were raised upon within the project-related documents. They explored respondents' role in the project, positive and negative experiences related to the management planning practices, and the establishment and continuation of management actions. Because the survey was done four years after the project ended, it was also possible to explore how well respondents recalled their participation in the project. Those respondents who did not remember having any relation to the project were directed to fill in their background information without completing the first part.

The latter part of the questionnaire included questions on respondents' demographic information and current livelihood. In the end of the questionnaire an opportunity to leave open-ended feedback was offered. 
Because of the bilingual nature of the project's operational region, the questionnaire was available in Finnish and in Swedish.

\section{Results}

In total, the management planning resulted in 137 site-specific plans, which were used in 117 AES payment applications from farmers and 14 from civic associations. The plans encompassed ca. 400 ha of conservation and Natura 2000 areas, 220 ha of surveyed TRBs classified as biologically valuable, and 380 ha of other landscape management sites.

\subsection{Outcomes of the project fromadministration's perspective}

\subsubsection{Good practices}

The final report of the project underlined the importance of targeted high-quality guidance for people involved in landscape management. Here a crucial point was that the project put more effort to site-specific management planning when compared to the usual situation where planning was done either by the manager him-/herself, or the manager bought a ready-made management plan from an advisor.

Local communities were involved in landscape management planning and implementation of the planned actions. This participation was based on voluntariness; locals contacted the project workers and suggested potential management sites. During field visits to these sites, the project workers evaluated the suitability of the sites for grazing and provided additional information on biodiversity and local landscape values. Afterwards, the workers arranged opportunities for shared local efforts to manage sites considered as valuable (see Fig. 4). As stated in the project's documentation, "the project demonstrates the importance of involving all concerned stakeholders, namely local people, in the appropriate landscape management of their areas and in their commitment to carry on the aims of the project after its initial funding stopped" (Council of Europe 2015). Engaging local actors into this collaborative planning process facilitated management continuity, and a cooperation network model enabled grazing arrangements among landowners and cattle owners. New collaboration initiatives can be made via the Pasture Bank website.

Farms benefited from indirect income related to TRB management. Although the management payments are based on compensation of costs, extensive grazing on TRBs both frees arable land from pasturage to cultivation and provides additional pasture that allows for more productive cattle husbandry. Also, the project enabled spreading of new business activities, which are compatible with landscape management, such as rural tourism and direct sales.

During the project, the workers gathered knowledge accumulated from prior projects in order to develop management plans that would better reach both the interests of the landowners and cattle farmers, but also benefit biodiversity. As experiences were exchanged, collaboration between provinces was tightened. Project's activities and outcomes were communicated to project participants and the general public in order to further generate and share knowledge. This included informing people of the opportunities to engage in site-specific and largescale landscape management planning, the advance of planning processes, and the initiation of planned management. Announcements and articles in local newspapers were most often used in the beginning of the planning processes. As the planning proceeded, one-directional communication was replaced by encounters of project workers and locals in group and face-to-face meetings. When sites were taken into management, the benefits of grazing were again publicly communicated.

\subsubsection{Lessons learnt}

Also more critical points of view were mentioned. The demand for advisory services on TRB and landscape management exceeded the expectations. The target was to contact 450 persons; in total, personalized advice on grazing management and AES payments was given to 489 persons. In addition, the final report 
mentioned that the number of management site initiatives from locals was so high that all valuable sites could not be placed into management planning. It became clear that there is lack of knowledge on the biological value of TRBs, their management practices, and funding opportunities.

Some non-farming landowners were reluctant to rent their TRBs for application of management payments. Rental contract was requisite for payment application, if the applicant did not hold possession of the site. Sometimes non-farming landowners had economic interests for the site, and these needs were difficult to meet in the collaborative planning process. Because rental fees could not be covered by the payments, cattle owners were unable to pay the landowners enough money and simultaneously retain the profitability of TRB leasing.

Based on project participants' accounts, the payment contracts proved to be highly bureaucratic, and this lowered their appeal. Especially representatives of civic associations found the paperwork involved in the AES burdening. For them, it was also difficult to make a five-year commitment to payment contracts, as the board of the association usually changes on yearly basis. The new TRB restoration measure was experienced as extremely bureaucratic, since it demanded a separate accounting, detailed notes on the execution of the site restoration plan, and it was paid retrospectively according to realized costs, which created an economically unreasonable situation in some occasions.

\subsection{Feedback from the participant questionnaire}

\subsubsection{Respondent characteristics}

A total of 63 respondents answered to the feedback questionnaire (Supplementary material 2), giving a response rate of $19.1 \%$.

Receiving on-site landscape management counseling was the most common type of project participation among the respondents. These activities included field visits done by project workers $(n=39)$ and sitespecific management planning $(n=35)$. They were followed by off-site advisory services through phone ( $n=13$ ) and large-scale landscape management planning $(n=10)$. Ten respondents did not remember participating in the project.

\subsubsection{Evaluation on project's operations}

In general, respondents were satisfied with their participation in the project. When asked to list three project activities they considered successful, site-specific management and funding counseling received most votes (Fig. 5). The three most successful individual practices were participatory; these included field visits, counselling, and sitespecific management planning. Three activities experienced as unsuccessful were securing management continuity, spreading information on landscape management, and supporting entrepreneurship on landscape management. Less than half of the respondents (29/63) answered to the question of the project's shortcomings. Three of those, who passed over the question, commented that they either could not answer or did not have negative experiences. One farmer experienced that the whole project failed. In this case the site-specific management plan was unfeasible, partially because of her personal situation, which was not properly accounted for in the planning process.

Respondents reacted mainly positively to statements expressing contentment in different aspects of project's operations (Fig. 6). The advisory services on landscape management and AES counseling were considered professional and participants were left with a general positive image of the project. Most participants $(42 / 49 ; 85.7 \%)$ expressed a wish for similar activities to be established in the future, which was also reflected in a mixed response to project's duration. One interest group representative commented that the project could have lasted for a longer time. In contrast, one landowner strongly disagreed with the claim that future actions similar to the project are needed. This opinion was not based on personal experience from the project, but rather on a general perception of landscape management as unnecessary, as he stated in an open comment.

Most of the criticism was targeted towards formation of cooperative management networks; however, there was also positive feedback. The project was more efficient in strengthening existing 


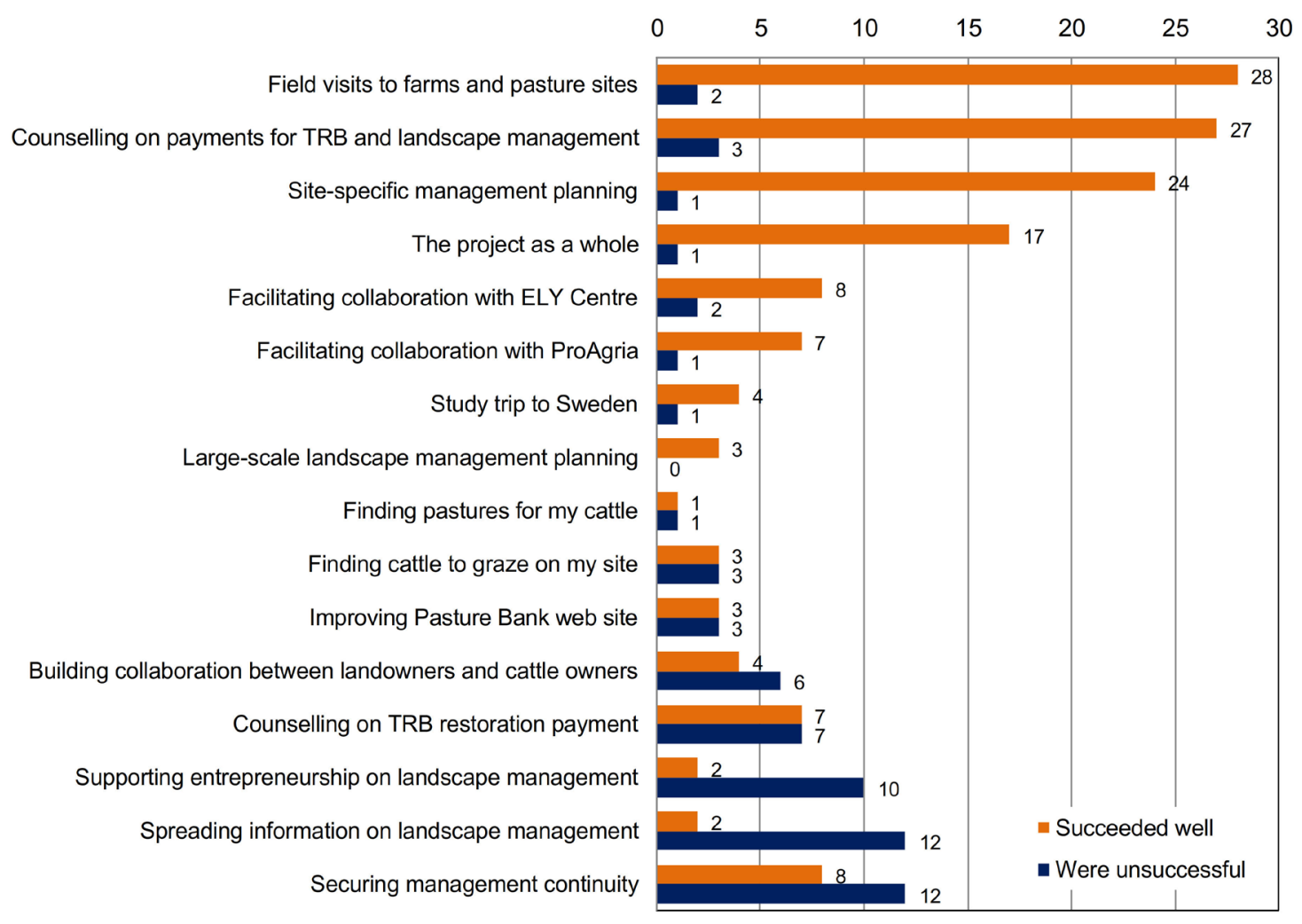

Figure 5: Activities of the project that were considered either successful or unsuccessful. First, respondents were asked to choose three activities they had experienced most positive (numbers of mentions are depicted in orange bars; $n_{\text {total }}=148$ ). Then, the same list of activities was presented again and participants chose which three project activities failed based on their experience (blue bars, $\left.n_{\text {total }}=65\right)$.

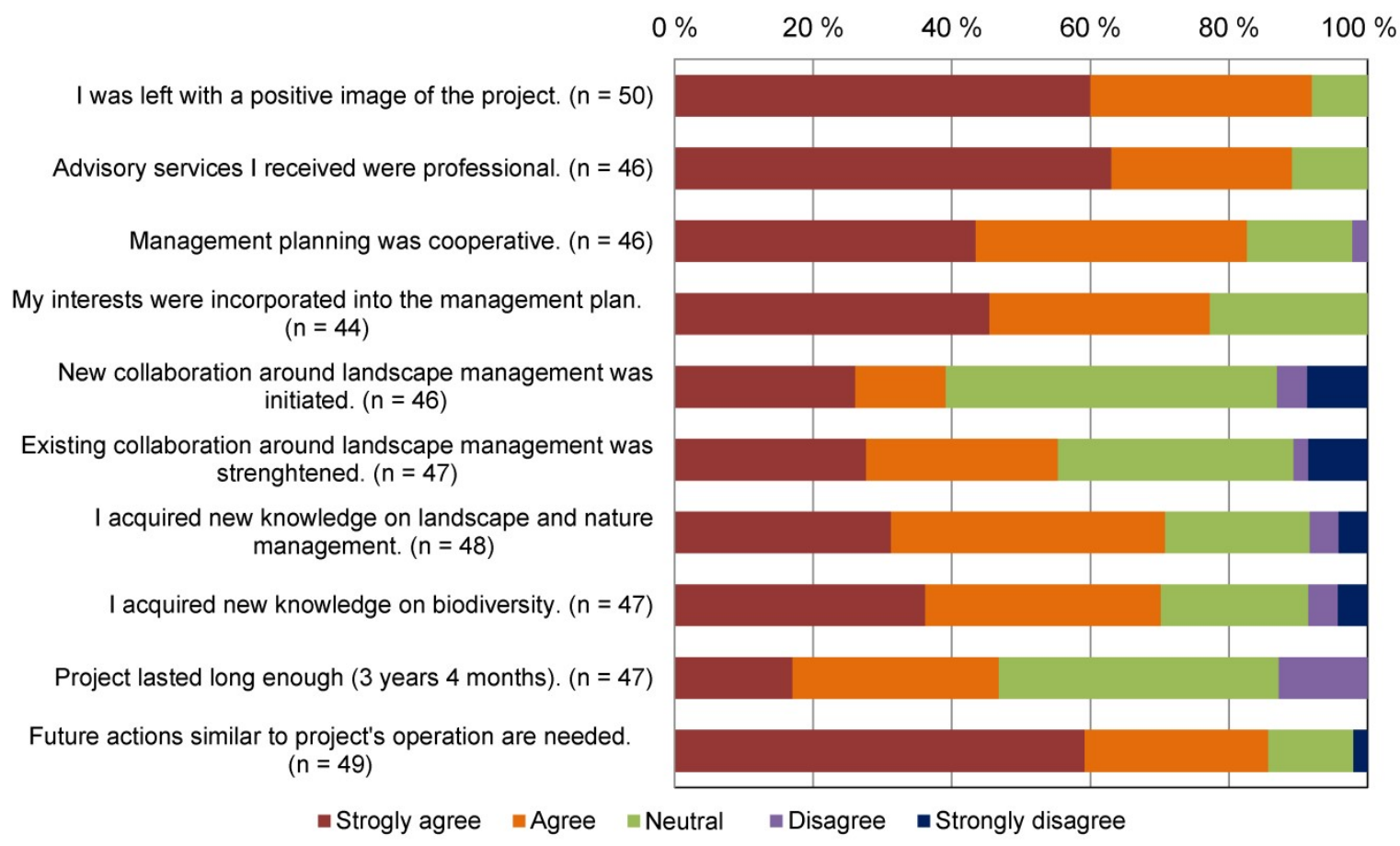

Figure 6: Respondents' agreement with statements reflecting contentment to the project. For each statement, respondents chose the alternative that best corresponded to their own experience 
collaboration than initiating new networks. There were some respondents who disagreed with the claim that the project provided them with new knowledge on biodiversity or management actions (4/47 and 4/48, respectively). One of them, a civic association representative, mentioned that he was already familiar with the issues.

Those respondents, who were not involved in the management planning processes, felt it difficult to evaluate particular activities. This was reflected both in the open comments and in the number of neutral responses to contentment statements. Furthermore, one farmer said that because of the time since the project, she could not remember all things related to it.

\subsubsection{Implementation of management plans}

In most of the cases, site management had been implemented as planned (32/43; $74.4 \%)$. Six respondents $(14.0 \%)$ informed that the site was partially managed, and five respondents $(11.6 \%)$ said that the site was not managed at all. Management was likely to continue in the future according to 31 respondents $(72.1 \%)$. Four $(9.3 \%)$ said that management will cease, and the rest (8/43; $18.6 \%)$ evaluated that the continuation of site management was somewhat unsure.

Most respondents saw that site-specific management plans facilitated realization of management actions. Twelve out of $42(28.6 \%)$ considered the plan as very helpful, $24(57.1 \%)$ evaluated it as helpful or somewhat helpful, one saw it as of little help, and one said that the plan was not helpful at all. Four respondents $(9.5 \%)$ said they could not evaluate the plan's helpfulness.

Answers to open-ended questions clarified reasons behind failures of site-specific management plans. These most often were not related to the project's planning effort, but to unanticipated problems during the implementation of the plans. One farmer said that the regional ELY Centre had unilaterally cancelled the management contract in the middle of the contract period, but no specific reason for this was mentioned. Another farmer described how management of a shore meadow had failed because of water level rising caused by a downstream power plant.

In other cases, the management network had broken down. One landowner said that the planned manager had moved away, but she had been able to find a new collaborator. Two other respondents said that the continuation of the management was unsure because of changes in the landownership of the managed site.

The implementation of large-scale landscape management plans was less common. It was also clear that some respondents were confused on their involvement in large-scale planning. Although ten respondents announced they participated in the planning process, 19 respondents answered to the question on the implementation of the plans, and 22 respondents evaluated the usefulness of the plans. Six out of 19 (31.6\%) said that they had followed the plan accordingly. All of them remembered participating in the planning process. Another six respondents ( $31.6 \%$ ) said they had followed the plan partially. Three (15.8\%) said they had not followed the plan and four $(21.0 \%)$ were unsure on whether they had implemented the plan.

Large-scale landscape management plans were not considered as useful as site-specific management plans. One respondent out of 22 thought that the plan had been very useful, eleven $(50.0 \%)$ evaluated it as useful or somewhat useful, three (13.6\%) saw it as little useful, and the rest $(7 / 22 ; 31.8 \%)$ could not evaluate the plan's usefulness. One farmer commented that she considered the plan having only minor use because its implementation would have been too expensive and laborious on her behalf. Another farmer criticized the plan as ambiguous according to management sites.

\subsubsection{Open-ended feedback}

Further insight into project's outcomes was also given. Respondents suggested that the project would have benefited from additional measures that would have followed the planning and counseling activities. Particularly follow-up of management actions was hoped for in order to safeguard continuity of management. Some respondents also 
mentioned needs for practical help and financial support in implementation of the plans. Continuous interpretation of complex rules and regulations within the AES into straightforward guidelines was wished for.

In their final comments, nine respondents expressed gratitude towards the project's effort. The contribution of the project to their livelihood was seen as important, as can be seen in the following quotation:

"When we started beef production in 1994, our goal was to practice landscape management and produce environmentally friendly high-quality meat. After participating in the project, this has succeeded over expectations." - Cattle farmer

Another respondent provided a description of experienced landscape change:

"Finland's joining EU in year 1995 has led to acceleration of the structural change in agriculture, and to an end for small-scale cattle production. For this reason, old semi-natural pastures have been abandoned on many farms, and small farms die out. Sadly, the old rural idyll has disappeared. In the beginning of 1980s this village had more than hundred dairy farms, and now only ten to fifteen are left." - A landowner without cattle

The emotional aspect clearly motivates initiating landscape management. Above passage also exemplifies the way in which both national and international politics have transformed the local landscape. Also other participants understood how socioeconomic factors drive rural changes and lead to TRB loss, and they brought up the limitations of the project in counteracting these drivers. Yet, they felt that the project's actions were needed:

"The project is a good start. Biodiversity management should become a profitable livelihood for rural people. There are a lot of traditional landscapes that need to be managed, but the work should be economically reasonable." - A farmer without cattle.

\section{Discussion}

"Bull by the Horns" -project introduced adaptive governance practices, collaborative planning techniques, and stakeholder networking in landscape management in Finland. These approaches were expressed in site-specific management planning. As both project's administration and participants pointed out, site-specific planning relied on bottomup initiatives and local participation in management arrangements, combined with guidance and advice from project workers who represented regionallevel authorities and advisory organizations. Through this collaboration among officials, landscape management experts, civic associations, private landowners, and cattle farmers, the project provided insight into sustainable governance of cultural landscapes. Targeting management planning to valuable sites by counseling ensured that funding through AES payments advanced conservation of TRBs more effectively. Management actions were tailored according to the biological character of the sites, simultaneously taking the legal restrictions into account. Several sites that would have remained abandoned because of bureaucracy were brought within the coverage of the AES payments.

To reflect whether the project exemplifies adaptive co-management, its practices need to be contrasted against the framework's premises. According to Berkes (2007), the cornerstones of adaptive co-management are power sharing, institution building, trust building, social learning, problem solving, and better governance. Together these form a cyclical iterative process in which an enabling environment fosters learning through collaboration (Allen \& Garmestani 2015). Several of the principles of adaptive co-management were realized in the project's operations, and these, together with the shortcomings, are discussed in the following paragraphs.

By engaging local people in the planning process, the project created a common arena for authorities and locals to collectively define landscape and biodiversity management goals and practices. These were documented in the management plans. 
The project also lowered the barriers between the administration and local actors, providing an informal way to contact the officials responsible for TRB and landscape management payments and inspection. This enabled mutual cooperation and trust and network building around landscape management which is seen in the positive feedback from the project's participants. The participants considered field visits and site-specific counseling as highly valuable. This underlines how social context is crucial for the success of adaptive comanagement (Folke et al. 2005), and corresponds to earlier findings that trust and respect, common understanding, communication, time allocation, and local influence are important in creating successful local participation (Stenseke 2009).

Increased participation also demands for a development from sector-bound planning towards a more integrated landscape perspective (Stenseke 2009); in this case, integrated objectives of landscape management were sought for in face-to-face encounters during the field visits and planning occasions. Although conservation and management of TRBs is primarily driven by ecological factors, also historical, cultural, and agricultural values are of importance (Birge \& Fred 2011; Birge \& Herzon 2014; Raatikainen \& Barron 2017). Site-specific objectives of TRB management typically include conservational measures, such as restoration or maintenance of habitat heterogeneity and management of populations of rare species, together with provision of cultural ecosystem services, e.g. promoting landscape aesthetics and continuity of local heritage (Mussaari et al. 2012). The importance of these aims was evident in sitespecific collaborative management planning, but also the relevance of economic aspects was underlined. Although economic benefits are refused as the primary motivation for TRB management (Birge \& Herzon 2014), the accounts of authorities and project's participants indicate that indirect income from TRB management is essential in sustaining it within contemporary rural livelihoods. Based on the participants' feedback, more effort is needed to secure the profitability of landscape management initiatives.
Communicative determination of values and vision underlying the management actions is an important feature in adaptive co-management process (Olsson et al. 2004). This process is referred to as sensemaking (Olsson et al. 2004). Inclusion of aspects on the future of farming and acknowledging the importance of local knowledge, experiences, and practices are important in planning of landscape management (Stenseke 2009). Most of the project's participants felt that their interests were incorporated into the management plans, and that the planning process was cooperative. Widening the landscape and TRB management discourse beyond nature conservation issues resulted in a common understanding on managementobjectives. Explaining conservational, agricultural, and entrepreneurial points of view clarified underlying values and meanings of conservation action for participants and project workers alike. This consensus-oriented dialogue is needed to foster quality and continuity of biodiversity management (McGinlay et al. 2017).

Also problem solving and social learning were established in the site-specific collaborative management planning process. Learning outcomes did not relate to new knowledge on biodiversity or landscape management practices per se, but more on general social-ecological characteristics of TRB management. The problems to be solved ranged from practical issues such as finding grazers to questions concerning land-use rights and management goals. New tools were developed to facilitate such issues: Pasture Bank -website aided in connecting landowners with cattle farmers, and a template for renting TRB pastures was created in order to enable AES contracts on hired sites. Management goals, on the other hand, needed sitespecific tailoring and could not be sorted out with a blueprint procedure. Therefore the crafting of sitespecific management plans paid effort to discussions among project workers and local stakeholders. This practice is rather new to Finnish environmental administration that has most often adopted a topdown controlled planning approach (for further discussion, see Kaljonen 2008). 
As a result, the project discovered management of TRBs as a complex and dynamic process. It brought forward the role of TRBs as habitats that simultaneously host both significant biodiversity value and provide important ecosystem services. These manifold experiential values are crucial in motivating TRB management (Birge \& Herzon, 2014; Raatikainen \& Barron 2017). Although TRBs are deeply linked to the history of Finnish agriculture and the practices of traditional farming (Salminen \& Kekäläinen 2000), their management has been and needs to be adjusted to the modern agricultural policies through AES funding and rural entrepreneurship (Birge \& Fred 2011). Biodiversitybased agriculture, which aims to develop ecosystem services provided by biological diversity, currently exists only as a niche (Duru et al. 2015). In order to navigate towards its productive potential, further efforts in developing innovative entrepreneurship on management for biodiversity within rural landscapes are needed. These could be supported by a transition from action-oriented to results-based agri-environmental measures (Matzdorf \& Lorenz 2010).

Similarly important for advancing TRB management is the formation of actor networks, which allow for one (or more) cattle owner(s) to manage several pastures owned by different landowners. As the results of the feedback questionnaire demonstrated, building such collaboration in top-down manner proved challenging, but supporting existing networks was more successful. Self-organized networks can expand, if given the opportunity. However, networking and realization of management cannot be left to local actors alone. Fragility of stakeholder networks is shown to threaten the quality and continuity of conservation management (McGinlay et al. 2017). As seen also in this case, actor networks may disintegrate and their rebuilding often would benefit from help and support from the authorities. This social-ecological dynamism is a strong reason for introducing adaptive co-management principles into TRB governance. Here, again, internet-based tools such as the Pasture Bank are able to facilitate actor networking in a bottom-up manner.
It seems that the authorities - represented by the "experts" involved in the project - learned more of contemporary TRB management than the project's participants. The latter saw that the project was unsuccessful in educating the general public on issues related to landscape management. However, knowledge cumulated through incorporation of local knowledge of landowners and farmers into management planning, and this was valued by the project's administration. It is common that in social learning processes both expert and non-expert knowledge play productive and essential roles (Olsson et al. 2004; Armitage et al. 2009). Multilevel social networks are able to generate and transfer knowledge and develop social capital as well as legal, political, and financial support to management initiatives (Folke et al. 2005). Through project's networks, knowledge on social-ecological functions and attributes of TRB and landscape management was further fed into AES development. This "bottomup" social learning process contributed to reframing the objectives and reducing the bureaucracy of TRB management measures in the AES for period 20142020 (Ministry of Agriculture and Forestry 2014).

From a more critical perspective, the project did not involve long-term institution building among local actors and government authorities; nor did it share decision-making power for locals. These shortcomings exemplify how difficult changing or modifying existing institutional structures is. Instead, the project utilized existing organizational setup and retained the ELY Centres' role as gatekeepers for management funding. This may be reflected in the failure of large-scale landscape management planning when contrasted to the success of sitespecific collaborative planning: in the former, the initiative for preparing a management plan for a specific region came from the authorities, and in the latter, the locals made the initiative. From the authorities' point of view, large-scale landscape management plans did not produce desired results in terms of new AES contracts. This shortage occurred despite the fact that the creation of the large-scale plans followed a well-established procedure (Kaljonen 2008). The implementation of planned management actions was dependent on 
the voluntariness of the landowners, and the project failed to stimulate self-organizing management within the planning regions. Nine large-scale plans were prepared, and although the project's final report mention that locals were responsive to the planning initiative, the results of the questionnaire show that several respondents were perplexed by large-scale landscape management plans. Thus it is likely that the large-scale planning process failed to engage the locals. This finding is in line with an earlier notion that the way in which the large-scale and site-specific management plans are linked to each other is critical for implementation and success of management actions (Kaljonen 2008). Clearly, largescale plans should have been complemented with more detailed site-specific management planning. It seems that authority-driven planning did not foster local involvement; instead, it may have strengthened the impression of top-down control, which is detrimental to participation (Stenseke 2009) and development of adaptive co-management (Olsson et al. 2004).

The ineffectivess in landscape-level planning may also be related to its scale. Larger-scale contexts in adaptive co-management tend to exacerbate challenges, whereas in small-scale systems the number of competing interests, institutional complexities, and layers of organization are lower, thereby mediating successful implementation of management efforts (Armitage et al. 2009). Concentrating on site-level management planning with fewer stakeholders indeed proved to be more flexible and efficient. Also other scale-related challenges emerged, namely in advisory services for TRB restoration payment, securing management continuity, supporting landscape managers' entrepreneurship, and spreading information on landscape management to general public. Although these were mentioned as important achievements according to project's administration (Council of Europe 2015), the participants evaluated them as less successful. It is evident that the project could not dismantle the bureaucracy of the restoration measure. Similarly, contributing to management continuity and profitability of rural livelihoods were out of the project's reach.
These observations relate to a more general scale mismatch in TRB conservation: the planning for and implementation of management actions is at a scale that does not reflect the scale of the problem (Guerrero et al. 2013). As the participants pointed out, many of the drivers of TRB decline and barriers for TRB management are connected to larger entities such as changes in livelihoods, rural depopulation, political structures, and agricultural market economy (see also Pelosi et al. 2010; Beilin et al. 2014; Raatikainen \& Barron 2017). Scale mismatches in social-ecological systems are difficult to resolve, and the solutions often require institutional changes at more than one hierarchical level (Cumming et al. 2006). Large-scale phenomena often are unattainable for projects (Lundin \& Söderholm 1995; Munck af Rosenschöld \& Wolf 2017). Yet, projects tend to be considered as more efficient and flexible when compared to more permanent organizations in environmental governance (Munck af Rosenschöld \& Wolf 2017). The importance of projects as a working method and funding source is growing in Finnish conservation administration because of scarcity of permanent resources. Therefore it is alarming that the environmental administration was unable to confront the scale mismatch in TRB conservation actions and drivers of TRB loss. This underlines the importance of including local actors' perceptions in order to reveal the inefficiency in governance.

Although the role of local actors was brought forth, the project did not induce permanent changes in the existing governance of TRB management in Finland. This is not surprising given the short time frame of the project (three years and four months). Leaving enough room for communication in participatory processes is resource-demanding (Stenseke 2009), and it is clear that additional long-term resources are needed in order to sustainably promote TRB management and measure the social and environmental outcomes more accurately. However, the heavy reliance on projects creates further risks. Long-term processes tied to organizational goals and overarching missions, such as institution building and development of functional follow-up systems, have proven difficult to foster through projectification (Munck af Rosenschöld \& Wolf, 
2017). Projects can pilot innovative policy measures, but the continuance of successful practices needs to be ensured through more reliable funding sources. This has occurred on some occasions, for example in Ireland where BurrenLife -project (conducted during years 2005-2010) was able to initiate more permanent results-based and cooperative measures that aim for agri-environmental stewardship (Burren Programme 2018).

Bull by the Horns, on the other hand, did not result in persistent institutional arrangements. Limited operative time frames are definitive for projects (Lundin \& Söderholm 1995) and they result in a typical failure: as the project ends, substantial amount of knowledge and practices are lost when successful strategies and methods are not documented, work is not described and analyzed, and future conditions for collaborative efforts are left uncertain as administrative executives change (Stenseke 2009). In addition to this institutional memory loss, projects' achievements tend to become forgotten through time also by the participants' behalf. This was seen also in this study, as several respondents did not remember their participation in the project. In addition, it is likely that many of the non-respondents had forgotten the project and therefore refused to participate in the questionnaire.

The project successfully targeted management payments to valuable sites, most of which still are under management, but the success in achieving the actual biodiversity outcomes has not been evaluated. The duration of the project was too short in order to organize a proper follow-up system for site management. Since management planning, applying for payments, and receiving funding decisions could last up to one and a half years, the first management actions initiated by the project were started when it was already past its midpoint. The need for proper ecological and social follow-up measures was acknowledged by both environmental administration and the project's participants, but the resources were and still are lacking for such work. Often TRB management proceeds in a sitespecific trial-and-error manner (e.g., which is the optimal length of a grazing period for a certain site). These experiments may well be conducted within action-oriented projects, but in order to achieve the desired biodiversity-related results of the management actions, their effectivity should be continuously followed and adjusted according to observed outcomes. The project provided important insight into how management should be arranged, but it failed to monitor the results of the management actions. This, again, could have been averted if the project would have continued for a longer time. In the end, the main goal of the project was to hinder the biodiversity loss caused by agricultural intensification and promote rural cultural landscapes. Although significant initiatives were made during the operative period in order to achieve this goal, it is impossible to say whether the management introduced by the project will prove successful in the long term.

As Koontz and Thomas (2006) argue, collaborative efforts in environmental management should be appropriately evaluated, as reaching agreement through collaboration does not always lead to projects or efforts that improve the environment. It is usual that studies on collaborative environmental management primarily focus on processes and easily measurable outputs rather than outcomes such as changes in biodiversity or perceptions of changes in environmental quality (Koontz \& Thomas 2006; Primmer et al. 2015). In order to learn from the lessons and good practices described in this paper, future projects on the same field should pay more attention to recording their combined socialecological effectivity, and securing long-enough operative periods.

\section{Conclusions}

Although this study focused on a single project, it provides insight into how biodiversity and landscape values depending on traditional rural land-use practices can be managed. Ecologically sound management needs to be adjusted to modern agricultural policies, financial support schemes, and 
entrepreneurial offsets. The experiences from "Bull by the Horns" -project demonstrate the importance of collaborative approaches in organizing and governing conservation of traditional rural biotopes. Involvement of both public authorities and local actors is important in enhancing TRB management.

Adaptive co-management framework was useful in analyzing strengths and weaknesses in promoting TRB management. Especially site-specific collaborative management planning process can be considered as a good example of adaptive co-management. However, the success of landscape management measures is context-dependent, and the example provided here most likely will not work as a blueprint elsewhere. The project demonstrated also some shortcomings, namely in institution building, large-scale landscape management planning, and verifying the desired environmental outcomes. One significant reason for these failures was the short operative period of the project. It is questionable how well TRB management can be promoted through projectification. Although significant initiatives can be made within a short time frame, achieving better TRB conservation requires time, resources, and adoption of adaptive governance.

Advancing TRB conservation needs a more holistic approach that takes into consideration the socialecological characteristics of TRBs, including the scale mismatch between management actions and drivers of TRB loss. Future research could concentrate on issues such as combining TRB management with current rural livelihoods, quantifying effectiveness of management policies and practices against environmental outcomes, and exploring the broad spectrum of values nested in TRBs and HNV farmland landscapes.

\section{Acknowledgements}

The author wishes to thank all participants and workers of the "Bull by the Horns" -project. Maj and Tor Nessling Foundation and Kone Foundation have provided support for her current work. Liisa Horppila-Jämsä, Ilona Helle, Jaana Höglund, and
Leena Nikolajev-Wikström offered invaluable help in preparing the questionnaire. The editor and anonymous referees provided constructive comments that helped to improve the quality of the original manuscript.

\section{References}

Aakkula, J. \& Leppänen, J. (eds.) 2014. Maatalouden ympäristötuen vaikuttavuuden seurantatutkimus (MYTVAS 3) - Loppuraportti. Maa- ja metsätalousministeriön julkaisuja 3/2014.

Allan, E.; Manning, P.; Alt, F.; Binkenstein, J.; Blaser, S.; Blüthgen, N.; Böhm, S.; Grassein, F.; Hölzel, N.; Klaus, V.H.; Kleinebecker, T.; Morris, E.K.; Oelmann, Y.; Prati, D.; Renner, S.C.; Rillig, M.C.; Schaefer, M.; Schloter, M.; Schmitt, B.; Schöning, I.; Schrumpf, M.; Solly, E.; Sorkau, E.; Steckel, J.; Steffen-Dewenter, I.; Stempfhuber, B.; Tschapka, M.; Weiner, C.N.; Weisser, W.W.; Werner, M.; Westphal, C.; Wilcke, W. \& Fischer, M. 2015. Land use intensification alters ecosystem multifunctionality via loss of biodiversity and changes to functional composition. Ecology Letters 18, 834-843. DOI:10.1111/ele.12469.

Allen, C.R. \& Garmestani, A.S. (eds.) 2015. Adaptive Management of Social-Ecological Systems. 1st ed. Springer Netherlands. DOI:10.1007/978-94-0179682-8.

Andersen, E.; Baldock, D.; Bennett, H.; Beaufoy, G.; Bignal, E.; Brouwer, F.; Elbersen, B.; Eiden, G.; Godeschalk, F.; Jones, G.; McCracken, D.; Nieuwenhuizen, W.; van Eupen, M.; Hennekens, S. \& Zervas, G. 2004. Developing a High Nature Value Farming area indicator. Copenhagen.

Ansell, C. \& Gash, A. 2007. Collaborative governance in theory and practice. Journal of Public Administration Research and Theory 18, 543-571. DOI:10.1093/jopart/mum032. 
Arico, S.; Bridgewater, P.; El-beltagy, A.; Finlayson, M.; Harms, E.; Program, S.; Hepworth, R.; Leitner, K.; Oteng-yeboah, A.; Ramos, M. A. \& Watson, R. T. 2005. Millennium Ecosystem Assessment, 2005. Ecosystems and Human Well-Being: Synthesis. Washington, D.C.

Armitage, D., F. Berkes \& Doubleday, N. 2007. Introduction: Moving beyond Co-Management. In Adaptive Co-Management: Collaboration, Learning, and Multi-Level Governance, ed. D. Armitage, F. Berkes, and N. Doubleday, 1-15. Vancouver: University of British Columbia Press.

Armitage, D.R.; Plummer, R.; Berkes, F.; Arthur, R.I.; Charles, A.T.; Davidson-Hunt, I.J.; Diduck, A.P.; Doubleday, N.C.; Johnson, D.S.; Marschke, M.; McConney, P.; Pinkerton, E.W. \& Wollenberg , E.K. 2009. Adaptive co-management for socialecological complexity. Frontiers in Ecology and the Environment 7, 95-102. DOI:10.1890/070089.

Armsworth, P.R.; Acs, S.; Dallimer, M.; Gaston, K.J.; Hanley, N. \& Wilson, P. 2012. The cost of policy simplification in conservation incentive programs. Ecology letters 15, 406-14. DOI:10.1111/j.14610248.2012.01747.x.

Arponen, A.; Heikkinen, R.K.; Paloniemi, R.; Pöyry, J.; Similä, J. \& Kuussaari, M. 2013. Improving conservation planning for semi-natural grasslands: Integrating connectivity into agri-environment schemes. Biological Conservation 160, 234-241. DOI:10.1016/j.biocon.2013.01.018.

Batáry, P.; Dicks, L.V.; Kleijn, D. \& Sutherland, W.J. 2015. The role of agri-environment schemes in conservation and environmental management. Conservation Biology 29, 1006-1016. DOI:10.1111/cobi.12536.

Beaufoy, G. \& Cooper, T. 2013. Guidance Document on the Application of the High Nature Value Impact Indicator 2007-2013. http://enrd.ec.europa.eu/ sites/enrd/files/fms/pdf/6A6B5D2F-ADF1-02103AC3-AD86DFF73554.pdf (Date: 29.11.2016).
Beilin, R.; Lindborg, R.; Stenseke, M.; Pereira, H.M.; Llausàs, A.; Slätmo, E.; Cerqueira, Y.; Navarro, L.; Rodrigues, P.; Reichelt, N.; Munro, N. \& Queiroz, C. 2014. Analysing how drivers of agricultural land abandonment affect biodiversity and cultural landscapes using case studies from Scandinavia, Iberia and Oceania. Land Use Policy 36, 60-72. DOI:10.1016/j.landusepol.2013.07.003.

Berkes, F. 2007. Adaptive co-management and complexity: exploring the many faces of comanagement. In Adaptive Co-Management: Collaboration, Learning, and Multi-Level Governance, ed. D. Armitage, F. Berkes, and N. Doubleday, 19-37. Vancouver.

Berkes, F.; Colding, J. \& Folke, C. 2003. Navigating Social-Ecological Systems: Building Resilience for Complexity and Change. West Nyack, NY.

Birge, T. \& Fred, M. 2011. New ideas for old landscapes: using a social-ecological approach for conservation of traditional rural biotopes - a case study from Finland. European Countryside 3, 133-152. DOI:10.2478/v10091-011-0008-x.

Birge, T. \& Herzon, I. 2014. Motivations and experiences in managing rare semi-natural biotopes: A case from Finland. Land Use Policy 41, 128-137. DOI:10.1016/j.landusepol.2014.05.004.

Burren Programme. 2018. Burren Programme - Farming for Conservation. http:// burrenprogramme.com (Date: 22.2.2018)

Council of Europe 2009. European Landscape Convention. Florence: Council of Europe.

Council of Europe 2015. Landscape award of the Council of Europe, 4th session 2014-2015. Report of the meeting of the international jury. Strasbourg. 
Cumming, G.S.; D.H.M. Cumming \& Redman, C.L. 2006. Scale mismatches in social-ecological systems: causes, consequences, and solutions. Ecology and Society 11 (1), 14.

Duru, M.; Therond, O. \& Fares, M. 2015. Designing agroecological transitions; A review. Agronomy for Sustainable Development 35, 1237-1257. DOI:10.1007/s13593-015-0318-x.

Folke, C. 2006. Resilience: The emergence of a perspective for social-ecological systems analyses. Global Environmental Change 16, 253267. DOI:10.1016/j.gloenvcha.2006.04.002.

Folke, C., Carpenter, S.; Elmqvist, T.; Gunderson, L.; Holling, C.S. \& Walker, B. 2002. Resilience and sustainable development: building adaptive capacity in a world of transformations. Ambio 31, 437-440.

Folke, C.; Hahn, T.; Olsson, P. \& Norberg, J. 2005. Adaptive governance of social-ecological systems. Annual Review of Environment and Resources 30, 441-473. DOI:10.1146/annurev. energy.30.050504.144511.

Guerrero, A.M.; McAllister, R.R.J.; Corcoran, J. \& Wilson, K. A. 2013. Scale mismatches, conservation planning, and the value of socialnetwork analyses. Conservation Biology 27, 3544. DOI:10.1111/j.1523-1739.2012.01964.x.

Heikkinen, I. (ed.) 2007. Luonnon puolesta - ihmisen hyväksi. In Finnish. Helsinki.

Henle, K.; Alard, D.; Clitherow, J.; Cobb, P.; Firbank, L.; Kull, T.; McCracken, D.; Moritz, R. F. A.; Niemelä, J.; Rebane, M.; Wascher, D.; Watt, A. \& Young, J. 2008. Identifying and managing the conflicts between agriculture and biodiversity conservation in Europe - A review. Agriculture, Ecosystems \& Environment 124, 60-71. DOI:10.1016/j. agee.2007.09.005.
Kaljonen, M. 2008. Bringing back the lost biotopes: the practice of regional biodiversity management planning in Finland. Journal of Environmental Policy \& Planning 10, 113-132. DOI:10.1080/15239080801928394.

Kemppainen, R. \& Lehtomaa, L. 2009. Perinnebiotooppien hoidon tila ja tavoitteet. In Finnish. Turku.

Kleijn, D. \& Sutherland, W.J. 2003. How effective are European agri-environment schemes in conserving and promoting biodiversity? Journal of Applied Ecology 40, 947-969. DOI:10.1111/ j.1365-2664.2003.00868.x.

Koontz, T.M. \& Thomas, C.W. 2006. What do we know and need to know about the environmental outcomes of collaborative management? Public Administration Review 66, 111-121. DOI:10.1111/ j.1540-6210.2006.00671.x.

Kuussaari, M.; Tiainen, J.; Helenius, J.; Hietala-Koivu, H. \& Heliölä, J. 2004. Maatalouden ympäristötuen merkitys luonnon monimuotoisuudelle ja maisemalle: MYTVAS-seurantatutkimus 20002003. Vammala.

Linnell, J.D.C., Kaczensky, P.; Wotschikowsky, U.; Lescureux, N. \& Boitani, L. 2015. Framing the relationship between people and nature in the context of European conservation. Conservation Biology 29, 978-985. DOI:10.1111/cobi.12534.

Lundin, R. A. \& Söderholm, A. 1995. A theory of the temporary organization. Scandinavian Journal of Management 11, 437-455. DOI:10.1016/09565221(95)00036-U.

Matzdorf, B. \& Lorenz, J. 2010. How cost-effective are result-oriented agri-environmental measures?-An empirical analysis in Germany. Land Use Policy 27, 535-544. DOI:10.1016/j. landusepol.2009.07.011. 
McGinlay, J.; Gowing, D.J.G. \& Budds, J. 2017. The threat of abandonment in socio-ecological landscapes: Farmers' motivations and perspectives on high nature value grassland conservation. Environmental Science \& Policy 69, 39-49. DOI:10.1016/j.envsci.2016.12.007.

Ministry of Agriculture and Forestry 2013. Rural Development Programme for Mainland Finland 2007-2013. Helsinki.

Ministry of Agriculture and Forestry 2014. Rural Development Programme for Mainland Finland 2014-2020. Helsinki.

Munck af Rosenschöld, J. \& Wolf, S. A. 2017. Toward projectified environmental governance? Environment and Planning A 49, 273-292. DOI:10.1177/0308518X16674210.

Mussaari, M.; Käyhkö, N.; Haggrén, G.; Jansson, H.; Lindgren, L.; Pitkänen, T. \& Raatikainen, K. 2012. Management guidelines for semi-natural landscapes - integrating historical perspectives and GIS into planning process. Turku.

Olsson, P.; Folke, C. \& Berkes, F. 2004. Adaptive comanagement for building resilience in socialecological systems. Environmental Management 34, 75-90. DOI:10.1007/s00267-003-0101-7.

Pasture Bank. 2017. Laidunpankki. http://www. laidunpankki.fi (Date: 3.2.2017)

Pelosi, C.; Goulard, M. \& Balent, G. 2010. The spatial scale mismatch between ecological processes and agricultural management: Do difficulties come from underlying theoretical frameworks? Agriculture, Ecosystems \& Environment 139, 455462. DOI:10.1016/j.agee.2010.09.004.

Plieninger, T. \& Bieling, C. 2013. Resilience-based perspectives to guiding high-nature-value farmland. Ecology and Society 18: 20.

Plieninger, T.; Höchtl, F. \& Spek, T. 2006. Traditional land-use and nature conservation in European rural landscapes. Environmental Science \& Policy 9, 317-321. DOI:10.1016/j.envsci.2006.03.001.

Plieninger, T.; Hartel, T.; Martín-López, B.; Beaufoy, G.; Bergmeier, E.; Kirby, K.; Montero, M.J.; Moreno, G.; Oteros-Rozas, E. \& Van Uytvanck, J. 2015. Wood-pastures of Europe: Geographic coverage, social-ecological values, conservation management, and policy implications. Biological Conservation 190, 70-79. DOI:10.1016/j. biocon.2015.05.014.

Primdahl, J.; Kristensen, L. S. \& Swaffield, S. 2013. Guiding rural landscape change. Current policy approaches and potentials of landscape strategy making as a policy integrating approach. Applied Geography 42, 86-94. DOI:10.1016/j. apgeog.2013.04.004.

Primmer, E.; Jokinen, P.; Blicharska, M.; Barton, D.N.; Bugter, R. \& Potschin, M. 2015. Governance of ecosystem services: A framework for empirical analysis. Ecosystem Services 16, 158-166. DOI:10.1016/j.ecoser.2015.05.002.

Raatikainen, K.J. \& Barron, E.S. 2017. Current agrienvironmental policies dismiss varied perceptions and discourses on management of traditional rural biotopes. Land Use Policy 69, 564-576. DOI:10.1016/j.landusepol.2017.10.004.

Raatikainen, K.J.; Mussaari, M.; Raatikainen, K.M. \& Halme, P. 2017. Systematic targeting of management actions as a tool to enhance conservation of traditional rural biotopes. Biological Conservation 207, 90-99. DOI:10.1016/j.biocon.2017.01.019.

Rassi, P.; Hyvärinen, E.; Juslén, A. \& Mannerkoski, I. (eds.) 2010. The 2010 red list of Finnish species. Helsinki.

Raunio, A.; Schulman, A. \& Kontula, T. (eds.) 2008. Assessment of threatened habitat types in Finland. Vammala. 
Salminen, P. \& Kekäläinen, H. 2000. Perinnebiotooppien hoito Suomessa: Perinnemaisemien hoitotyöryhmän mietintö. In Finnish. Helsinki.

Schulman, A.; Alanen, A.; Hæggström, C.-A.; Huhta, A.-P.; Jantunen, J.; Kekäläinen, H.; Lehtomaa, L.; Pykälä, J. \& Vainio, M. 2008. Perinnebiotoopit. In A. Raunio, A. Schulman \& Kontula, T. (eds.): Suomen luontotyyppien uhanalaisuus - Osa 2: Luontotyyppien kuvaukset. Suomen ympäristö 8/2008.

Stenseke, M. 2009. Local participation in cultural landscape maintenance: Lessons from Sweden. Land Use Policy 26, 214-223. DOI:10.1016/j. landusepol.2008.01.005.

Uthes, S. \& Matzdorf, B. 2013. Studies on agrienvironmental measures: A survey of the literature. Environmental Management 51, 251266. DOI:10.1007/s00267-012-9959-6. 